Sarpong, David and Adams, Kweku

ORCID: https://orcid.org/0000-0002-3737-954X (2019) The Mabey and Johnson bribery Scandal: A Case of Executive Hubris.

Thunderbird International Business Review, 61 (2). pp. 387-396.

Downloaded from: http://ray.yorksj.ac.uk/id/eprint/3060/

The version presented here may differ from the published version or version of record. If you intend to cite from the work you are advised to consult the publisher's version: https://onlinelibrary.wiley.com/doi/abs/10.1002/tie.21989

Research at York St John (RaY) is an institutional repository. It supports the principles of open access by making the research outputs of the University available in digital form. Copyright of the items stored in RaY reside with the authors and/or other copyright owners. Users may access full text items free of charge, and may download a copy for private study or non-commercial research. For further reuse terms, see licence terms governing individual outputs. Institutional Repository Policy Statement

\title{
RaY
}

Research at the University of York St John

For more information please contact RaY at ray@yorksj.ac.uk 


\section{The Mabey and Johnson bribery Scandal: A Case of} Executive Hubris

\begin{tabular}{|r|l|}
\hline Journal: & Thunderbird International Business Review \\
\hline Manuscript ID & TIBR-17-028.R2 \\
\hline Wiley - Manuscript type: & Research Article \\
\hline Keywords: & Bribery, Executive hubris, Mabey and Johnson, Jamaica, Ghana \\
\hline \multicolumn{2}{|l}{} \\
\hline
\end{tabular}

\footnotetext{
SCHOLARONE ${ }^{\text {M }}$

Manuscripts
} 


\title{
The Mabey and Johnson bribery Scandal: A Case of Executive Hubris
}

\begin{abstract}
Convicted for paying bribes to secure contracts abroad, Mabey and Johnson (MEJ), a UK construction firm, made both legal and international business history. Drawing on hubris as a lens, we examine MEJ's bribery scandal in Ghana and Jamaica. Through a qualitative study of court documents, witness statements, newspaper articles, and internal company emails, we unpack the bribery scheme operated by MEJ executives that enabled the firm to illegitimately win major government contracts in Ghana and Jamaica. Fuelled by executive hubris, we found MEJ's practice of bribing foreign officials to secure contracts effectively insulated MEJ executives from day-to-day realities. Overtime, the firm's executives viewed themselves as infallible, exempt from established mores, invincible, and unremorseful for their actions. Building on these findings; we develop a hubris-bribery heuristic framework showing how individual, organizational, and institutional context constitutively fuelled executive hubris to drive bribery at MEJ. The implication for theory and practice are examined.
\end{abstract}

Keywords: Bribery, corruption, Ghana, Jamaica, executive hubris, Mabey and Johnson

\section{Introduction}

Recent bribery and corruption scandals involving global firms like Enron, Siemens, BAE systems, Daimler-Chrysler, Alcatel, and Volkswagen, shows that bribery and corruption is a much wider problem in international business. But in 2011, Mabey and Johnson (M\&J), a UK construction firm, made both legal and international business history for being the first British firm to be convicted for paying bribes to secure contracts in Ghana and Jamaica. Possibly the most important case in the history of the UK Serious Fraud Office (SFO), the M\&J scandal is the first known case where individual employees were given prison sentences for being involved in bribery abroad. The main purpose of this paper is to examine the firm's behaviour and how it organised its illegitimate practices at the blind side of the law. Specifically, we draw on executive hubris as a lens to analyse how the (in) actions of M\&J executives might have contributed to the firm engaging in bribery abroad. We argue that executive hubris as a meta-theoretical has the potential to extend our understanding as to whether, and how executive sense of invisibility and illusion of control may contribute to them consciously breaking rules overseas to gain advantage over competitors.

Empirically, we draw on a qualitative study of archival materials, including court documents, witness statements, company emails, and newspaper articles on the M\&J bribery scandal. The paper contributes to the literatures on executive hubris and bribery in international business in the following ways: First, while established body of scholarship has noted that bribery is rife in 
international business (Sanyal, 2012; Sanyal \& Samanta, 2004; Baughn, Bodie, Buchanan \& Bixby, 2010), this paper provides insight into the organizing processes through which international businesses bribe foreign officials. Second, by drawing on the case of the first UK firm to be prosecuted for paying bribes abroad, our paper opens up new possibilities for re-thinking why some organizations may be more prone to breaking sanctioned rules than others when operating abroad.

The rest of the paper is organised as follows. First, we provide a brief review of the existing literature on corruption and bribery in international business after which we present hubris as a theoretical lens to understanding bribery in international business. Following this, we provide an overview of M\&J and the bribery cases that led to the company's conviction, and the research methodology underpinning our empirical inquiry. Next, we present our research findings. Our discussion and conclusion section summarizes key findings, and highlights the contribution and limitations of our study.

\section{Bribery in International Business}

Bribery refers to the practice of offering something, usually money, to gain an illicit business advantage. A cog in national economic progress, bribery 'sands the wheels of growth', leads to inefficiencies, and translate into high additional transaction cost for businesses (Méon \& Sekkat, 2005; Shleifer \& Vishny, 1993). Despite the existence of market monitoring mechanisms and a plethora of trans-national legislations aimed at fighting the canker, the prevalence of corruption and bribery in international business remains high (Cuervo-Cazurra, 2016; Zeneli, 2016). Organizations, frequently engage in bribery and corruption to further their interests (obtain cheap capital or valuable information), gain lucrative contracts; help them to deal with bureaucratic institutions, surmount high policy uncertainty, and weak legal systems (Coleman 1989; Hellman, Jones \& Kaufmann, 2003).

In the IB context, bribery can be triggered by environmental pressures (Ashforth, Goia, Robinsin, \& Trevino, 2008), and can even be part of commercial transactions in some cultures (Sanyal, 2005; Steidlmeier, 1999). For example, $80 \%$ of businesses in Russia are suspected to pay bribes 
(Economist, 2008). In Asia, while it is not openly encouraged, bribery is more culturally accepted (Li \& Tang, 2010). Such ambiguous global ethical standards (Logsdon \&Wood, 2005), on what constitutes bribery raises doubt about the effectiveness and reliability of universal corruption standards. Rodriguez, Uhlenbruck \& Eden (2005), the discretionary power of public officers over the distribution of resources is the main driver for firms to engage in corrupt behaviour. Studies on agency theory based on the non-benevolent principal or "grabbing hand" also tend to view government officials as corruptible, through having a power to regulate entry to the market and create market distortions by their policies (Shleifer \& Vishny, 1998). From this perspective, government officials in places where institutions are weak, frequently have an even higher discretionary power over the allocation of resources, giving them power to create policies that have the potential to generate corruption opportunities (Aidt, 2003; Zhou \& Peng, 2012).

Firm-level evidence suggest that while small and medium size firms may be considerably hurt by bribery, and usually coerced into it, large firms sometimes benefit from it, albeit, in the shortterm when they strategically deploy it to remove obstacles, undermine their rivals, and build up their connections with their host countries governments to entrench their competitive positions (Zhou \& Peng, 2012; Straub, 2008). Nevertheless, more than $73 \%$ of financial fraud related enforcement actions, as argued by Anderson, Martin \& Reid (2015) take place in family firms. This goes to show that bribery and corruption is not only pervasive in contemporary organizing, it is particularly rife in family firms ( $\mathrm{Wu}, 2009)$. In this regard, business executives involved in bribery may be either ignorant of its ethical implications or are so self-consumed with their own and their firm's success that they build a wall of invincibility around them or turn a blind eye to deviant practices taking place in the firm (Baughn, Bodie \& Buchanan, 2010). In such context, unethical activities may become takenfor-granted, and sometimes, unconsciously embedded in organizing practices through a normalization process until they become an integral part of everyday business conduct (Fein and Weibler 2014a). Thus, while organisations are likely to engage in unethical behaviour (e.g. bribery) to further some organisational interests (Coleman, 1989, Pinto, Leana, \& Pil, 2008), they will only engage 
in illicit activities if the top management believes in the potential gains of these activities (Ashforth and Anand, 2003; Shleifer \& Vishny, 1993). For Rodriguez, Uhlenbruck \& Eden (2009) found that it is not the firm's professional connections to governments that result in government and business corruption. Rather, it is the personal ties and connections of individual executives that provide the potentialities and possibilities to employ bribery as a strategy for achieving firm success.

Taking our lead from Magnam, Cormier, \& Lapointe-Antunes (2010), we argue that executive hubris is "a missing link" in studies that examines executive involvement in the perpetuating of bribery in international business. This indicates that extant theory on bribery and corruption faces a significant challenge in explaining why managers will risk their organizational reputation, and sometimes their own careers in paying bribes to gain illicit business advantage. Bendahan, Zehnder, Pralong \& Antonakis, (2014) focusing on power and testosterone as a prediction of corruption concluded that even the most honest and moral individuals who reach the upper echelons of power may change their moral views. In that case if testosterone and power has the potential to make powerful people to believe they are 'invincible', then, we can safely argue that hubris as played out in the form of over-estimation of one's abilities, manipulation of rules, and contempt for authority (Hollow, 2014; Petit \& Mollaert, 2012) plays a salient role in making executives prone to engaging in corrupt practices, including, bribery to secure contracts and deals for their firm. In the next section, we delineate our hubris perspective on bribery.

\section{A Hubris Perspective on Bribery}

The term 'hubris' comes from ancient Greek mythology describing an act of a person in power, full of self-confidence and behaving with contempt for others (Owen, 2008; Owen \& Davidson, 2009). Thus, hubris syndrome is used to describe a person holding a position of power with minimal restrictions to exercise their power, and especially when they are irrationally self-confident, reluctant to listen to advice and act impulsively. People who suffer from this syndrome display the following characteristics; they tend to be overconfident, they overestimate their own abilities, overpraise their 
Relation with the self

Relation with others

Relation with the world
Has a grandiose sense of self
Behavioural aspects

Grandiose communication style (use of the royal "we"; use of superlatives; expression of overarching ambition)

Unjustifiably grandiose projects, Poor decisions

Entrenchment strategies

Considers him/herself uniquely and eternally qualified to run the company (accumulation of power; failure to accept removal from position; tardy resignation when circumstances would seem to dictate it)

Management by fear; violence or intimidation; refusal of advice or criticism

Fraud, manipulation of rules and laws, contempt towards authorities Source: Petit and Bollaert (2012).

Additionally, characteristic traits of successful leaders like charm, charisma, inclination to risk taking, great aspirations and self-confidence can lead to the development of executive hubris (Owen \& Davidson, 2009). Forbes (2005) and Owen \& Davidson (2009) propose that executive characteristics such as age, length of service and being the firm's founder, can also lead to the development of hubristic syndrome. For Hayward \& Hambrick (1997), what can be counted as hubristic behaviour arises from the belief in the success of an individual leader. As success is increased, their belief becomes more excessive, this is regardless of an individual's actual contribution to this success. In this environment, executives' over time may develop a strong self-belief and self-assurance in their abilities, effectiveness of their leadership and correctness of their decisions. However, in this process 
they may lose the track of reality and capacity to be self-critical. Historical superior performance of the firm and media praise for executive contributes and reinforces this self-belief (Hayward and Hambrick, 1997). In this regard, executive hubris has been used to explain executive decision making involving risk taking ( $\mathrm{Li} \&$ Tang, 2010), competitive games and entry to new markets (Camerer \& Lovallo, 1999; Hayward Shepherd \& Griffin, 2006). Most recently, it has been used as a lens to examine bankers' behaviour that led to the misjudgement of the nature and consequences of financial innovation that led to the 2008 financial crisis (Petit \& Bollaert, 2012; Brennan \& Conroy, 2013).

Although highlighted as being central to CEOs over-valuing assets and overpaying premiums in corporate acquisitions and mergers (Hayward, \& Hambrick, 1997; Hietala, Kaplan \& Robinson, 2002; Hiller \& Hambrick, 2005), executive hubris has received rather limited attention in the IB literature. However, with executives overestimating their own problem-solving abilities, performance, and probability of success (Malmendier \& Tate, 2005; Finkelston, 2009; Camerer \& Lovallo, 1999), scholars have gradually shifted their attention to executive hubris in an attempt to untangle the complex problem of firm failure, particularly after entry to new markets. Having fewer, if any, restrictions on their powers and behaviours, executives are more prone to hubris bias when compared to the general population (Owen \& Davidson, 2009; Claxton, Owen \& Saddler-Smith, 2015). When executives perform above their internal ambitions and external expectations (Mishina, Dykes, Block \& Pollock, 2010) they are rarely challenged, and in many cases their ideas are quickly actioned because the level of resistance may have been reduced by the effects of their hubris (Brown, 1993; Sherman \& Garland, 2007).

Generally, executive hubris could be restricted from developing by the board of directors when they prevent executives from making decisions that could be potentially damaging to shareholders (Hayward \& Hambrick, 1997, Turnbull, 2011). But this is not always the case as executive's self-esteem can be further strengthened by a CEO been a board member or when the vigilance of the board is lacking (Hayward \& Hambrick, 1997, Magnam, Cormier \& LapointeAntunes, 2010). This is likely to get exacerbated when executive discretion is higher, and external 


\section{The M\&J Bribery Scandal}

M\&J is a British engineering company that specialises in bridge construction. The firm is responsible for some of the major bridge constructions in the UK including Severn Bridge, and Avonmouth Bridge, and it specialises in supplying bridges to more than 115 countries; mainly in the developing world employing over 1100 people (Mabey Group, 2015). The company's contracts with foreign governments are frequently underwritten by the UK's Export Credit Guarantee Department (ECGD). Founded in 1923, by Guy Mabey, the company was taken over by his son Bevil Mabey in 1951, and remains one of the groups of companies owned by the Mabey Family. The Family owns majority of the shares in Mabey Holdings Ltd which is the parent company of Mabey Engineering (Holdings) Ltd. Bevil and his son David Mabey had executive roles in the management and activities of the group. Directors of the company were appointed or removed by the shareholders, Mabey family. Table 2 shows the individual tenure of past M\&J Executive Directors since its inception.

Table 2: M\&J's Executive Directors tenure

\begin{tabular}{lcc}
\hline Director & Length of service & Years in executive position \\
\hline Bevil Mabey & $1953-2007$ & 54 \\
Richard Forsyth & $1992-2008$ & 16 \\
Alan Daliday & $1992-2008$ & 16 \\
David Mabey & $1993-2008$ & 15 \\
Richard Glover & $1995-2009$ & 14 \\
Miles Potter & $1999-2008$ & 9 \\
\hline
\end{tabular}

Source: Fame, 2015

Bevil Mabey was the longest acting member of the family involved in the running of the company. He was the real driving force behind the growth of the business, turning this small family firm into a 
multi-million emporia, making the Mabey family the 141st richest family in the UK by 2008 (Evans \& Leigh, 2009). In 1984, Bevil Mabey personally received a CBE prize for services to the export industry (Mabey Group, 2015). The company received six Queen's Awards for Export Achievement (1973, 1978, 1982, 1987, 1998 and 2002). Yet, what on the outside seems like a tremendously successful company, turned out to be a company riddled with corruption on a global scale (Evans \& Leigh, 2009).

Reports that M\&J may be involved in paying bribes overseas came to light following the UK Guardian newspaper's follow-up investigation into accusations of overcharging and corruption levelled against M\&J by opposition parties in the Philippines (Leigh \& Evans, 2005). M\&J were accused of influencing politicians and government officials with bribes totalling $£ 470,000$ to win bridge contracts between 1994 and 1999 in Ghana. The company was also accused of making payments over $\$ 100,000$ to a Jamaican government minister and their agents to influence government decisions to award the company contracts for flyover and modular pre-fabricated bridges without a competitive bidding. Some of the illicit payments made by M\&J to overseas officials as listed in Table 3, suggests the symptomatic nature of bribery at M\&J.

Table 3: Examples of illicit payments made by M\&J to government officials

\begin{tabular}{ll}
\hline Dates & \multicolumn{1}{c}{ Ghana } \\
\hline Between & $-£ 55,000$ for 'Contract consultancy' to Minister of roads and highway \\
December & $-£ 500$ to Deputy Minister of Roads and Highways \\
1994 and 18 & $-£ 10,000$ to Director of Legal and International Affairs, Ministry of Finance \\
August 1999 & $-£ 10,000$ ex minister of Roads and Highway \\
& $-£ 5,000$ the director of the Legal and International Affairs at the Ministry of \\
& Finance at the Export Credit Guarantees Department, Ministry of finance. \\
& $-£ 15,000$ to Minister of Health \\
& $-£ 10,000$ to the Chairman inter-city transport corporation \\
& $-C h e q u e$ of $£ 500$ as 'additional education expense' to the son of a Desk Officer \\
\hline Dates & Jamaica \\
\hline Between 20 & -Minister of State in the Ministry of Transport and Works over the years \\
November & received approximately $£ 100,134.62$ \\
October 2001 & - M\&J's Agent was paid 12.5\% of the Jamaica 1 contract price \\
\end{tabular}


Despite overwhelming evidence, the company publicly denied authorising or paying bribes abroad to secure contracts (Leigh \& Evans, 2008). But after a year of long private negotiations with the SFO, they agreed to cooperate and admitted to corruption in Jamaica and Ghana (Leigh \& Evans, 2008, 2009). Before the trial, M\&J confirmed it would plead guilty to corruption offences and pay reparations for its misconduct. In February, 2011, M\&J director David Mabey was sentenced to eight months in prison. Managing director Charles Forsyth was sentenced to 21 months. The two in addition were disqualified from acting as company directors for five and two years respectively, and a third executive, Richard Gledhill, who gave evidence for the prosecution, was given an eight-month sentence suspended for two years. M\&J was also fined a record $£ 6.6$ million for paying bribes to overseas public officials in Ghana, Jamaica, as well as Iraq.

\section{Data Sources}

Given that we were interested in understanding bribery, a much wider problem in international business, we adopted an exploratory qualitative research approach (Maxwell, 2012), to enable us develop a comprehensive interpretive understanding (Thorne, 2016; Lee, 1991), of the M\&J bribery scandal. We developed our account by utilizing multiple archival records and publicly available information (Amankwah-Amoah, 2016) on the M\&J bribery scandal in Ghana and Jamaica. These included newspaper articles and summarised documents for other purposes, like the Southwark Crown Court hearings documents and court opening notes. The archival approach enabled us to critically follow the discourse that shaped the bribery scandal and understand the actions of M\&J executives in a context that would have been difficult or impossible to explore in practice (Gilliland \& McKemmish, 2004). We supplemented this with data taken directly from the websites of M\&J, SFO's website, the Justice Department, GhanaWeb, and internal company emails made available at the court hearings. As the weakness of one methodology lies in the strength of the other (Wiggins, 2011), our multiple data sources enabled us to develop a rich and detailed insight into the M\&J scandal that could not be achieved through a single source (Vissak, 2010). Analysis of the data led us to develop a 
detailed understanding of the scale and scope of the M\&J bribery scandal, and how executive hubris might have contributed or fuelled the directors' actions. We present the fine details of our findings in the next section.

\section{The Bribery Scheme Operated by M\&J in Ghana and Jamaica}

Whenever the government of Ghana or Jamaica approves finance for a project it initiates an official tender process by announcing the tender and inviting potential suppliers. The Public Procurement Board of Ghana or the Tender Evaluation Committee in Jamaica then forms an independent tender committee to oversee the process. The tender committee evaluates the individual proposals and capabilities of suppliers that bid for the project, and selects the one that meets the evaluation criteria and best matches the government requirements and budget. The contract is awarded, the winning supplier is notified and all other bidders debriefed. The winner then signs a legally binding agreement with the appropriate government agency outlining their responsibilities (Ghana Public Procurement Authority, 2003).

Our data evidence suggests that M\&J will normally bid for these contracts through the official process. However, the company actively undermined their commercial rivals by running a parallel tendering process. M\&J executives actively sourced public officials that had a power to affect M\&Js affair in the two countries. For their services agents were paid a commission between 5-15\%, representing part of the total price of each contract. To handle the payments of commissions, the special fund was created in Ghana. A similar contingency fund of $£ 1$ m was set up in Jamaica with all money being transferred to Deryk Gibson in 12 commissions between 2004 and 2006. Through their highly connected appointed agents, these funds were used to bribe powerful government officials who in turn will use their influence to get the individual Tender Boards to award contracts to M\&Jeven if their bids were overpriced. The bribes were simply being deducted directly from the agents' commissions and paid to the government officials involved. Figure 1 shows the official tendering process and how the parallel scheme run by M\&J operated in practice. 
Figure 1: The Mabey and Johnson bribery scheme

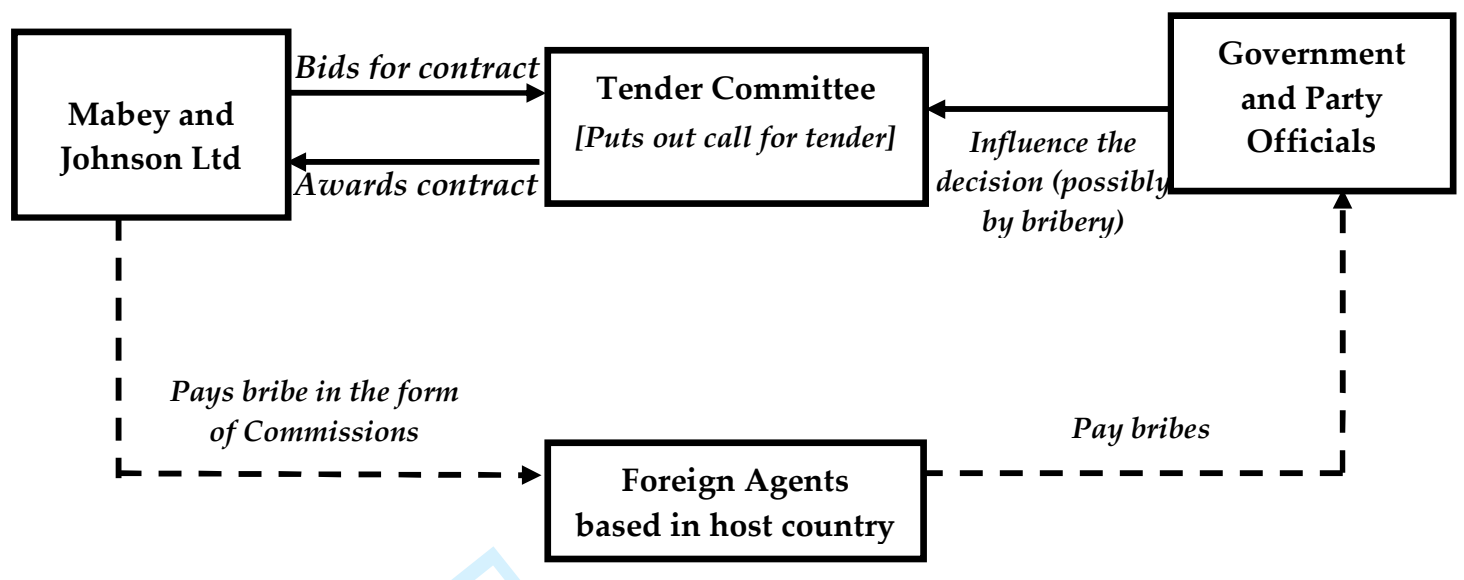

Mr Ofori, a director of a small Ghanaian bridge building company with extensive influence within the ruling party represented the company's interests from the mid-1980 to 1996. When his influence wore off he was sidelined and swiftly replaced with the more influential Baba Kamara; From 1994, Baba Kamara connected M\&J to the most powerful people in the then ruling party (The Southwark Crown Court, 2009a). Deryk Gibson, a former vice-president of the Jamaican Chamber of Commerce also represented M\&J in Jamaica. In an email to Gibson, for example, an M\&J director wrote:

J, sorry we did not hook up again, time just slipped by very quickly and before I knew it I was on a plane. No doubt you have a festive Xmas and New Year and I wish you well for 2006. Now back in JS and all is ok and a little payment just to start the year off, smile? $45,117.45$ to DAG, US equivalent $\$ 76,699.87$ with wire to you of $\$ 25,257.27$ with onward to B of $\$ 6,049.62$. Take care and a prosperous and peaceful 2006 for all, Saludos B (High Court of Justice Chancery Division, 2009).

While we concede this email is not entirely clear, its content signals a rather casual approach to bribery at M\&J. In stating the sums of money that were supposed to be forwarded onto additional individuals who helped the company secure a contract, the payment of bribes seems to be a routinized taken-for-granted business practice (Ashforth and Anand, 2003) at M\&J. In a related development is an email communication between a director and an agent:

As you are aware, Mr Hibbert is presently visiting the UK with two other colleagues. He has requested $£ 10,000$ cash to be deducted from the commission due to him (The Southwark Crown Court, 2009b). 
This particular communication suggests that illegal payments were authorised at the director level, making them directly responsible as the operators and supervisors of the scheme. Payments of bribes at M\&J became so casual to the extent that agents could even request parts of their payments at their convenience. The court also heard that Joseph Hibbert, a minister of state working for M\&J also received over $£ 100$, 000 between 1993 and 2001 for his services to M\&J directly from the commission fund (The Southwark Crown Court, 2009).

The normalization of bribery at M\&J led to the company adapting its bribery procedures when the Anti-Bribery Act and the Anti-Terrorism Crime and Security Act 2001 came into force. To comply with these new laws which could potentially make the payment of commissions above $5 \%$ raise suspicions, M\&J introduced the "artificial split" of commission (Leigh \& Evans, 2008). M\&J's sales director in the Caribbean described how the managing director decided to split the commission: 'Only 5\% would be called a commission and the rest called "after sale services" to make them look less significant in order not to raise suspicion'. M\&J made sure that it did not have to carry the burden of making these commission payments and they just simply increased the price of each contract. Furthermore, the company also tried to include other charges in the price of the contracts. This was clear in the following internal memorandum:

I am pleased to confirm we have now received from the Jamaican government $£ 1,212,420$ for the ECD premium which has been paid in full. Please note that this was included in our offer, but none the less, we have managed to get them to pay this, which increases our profit on the contract by that amount (The Southwark Crown Court, 2009b).

This memorandum refers a Jamaican contract worth $£ 14.9 \mathrm{~m}$ which includes a premium payable to Export Credit Guarantee Department (ECGD) for their guarantee. M\&J simply included this in the price of the contract, which is usually deducted from firm's profits; a point highlighted in the memorandum. The total cost of the contract was then further inflated by a $10 \%$ cost of commission; thus M\&J did not carry any of these costs while making a significant profit on the contract. Clearly, the company made this blatant false representation because they knew they could pressure the host government to comply through bribery. Most importantly, as a result of the executive hubris that has 


\section{Individual level}

At a fundamental level, individuals' actions and activities gave form and shape to executive hubris at M\&J. At the root of this were the personal, political, and the official ties M\&J executives cultivated with overseas government officials that constitutively drove the perpetuation of bribery with impunity. A former M\&J manager in court alluded that this culture was established by the founder who built very close relationships with presidents and government officials over the years and visited 
the homes of his agents on numerous occasions. These contacts were subsequently passed on to his successor and directors who were already socialized into the organisation's 'relationship building' with foreign government officials. In this regard, the close political networks developed over the years by the founder and the ensuing corporate success eventually evolved into M\&J's organizational culture supportive of bribing officials to secure contracts (Li \& Tang, 2013; Ashforth \& Anand, 2003). It should be noted here that it is not the firm's professional connections to officials that resulted in corruption but rather the personal connections of executives (Collins, Uhlenbruck \& Rodriguez, 2009). In this regard, M\&J directors were socialised into bribing to secure contracts, and took advantage of their own networks to maximise their personal self-interest. In the words of Williamson (1984: 198) they "act[ed] with guile, to engage in the full set of ex-ante and ex-post efforts" to bribe foreign government officials.

Also consistent with existing studies (e.g. Hayward \& Hambrick (1997; Owen, 2008; Collins, Uhlenbruck \& Rodriguez, 2009), our case analysis points to power and long service as salient contributors to the display of executive hubris at M\&J. Bevil Mabey held a leading position for 56 years with little constraint on his power. The other directors were also in post for a considerable number of years. For the Mabey family, their unchallenged control of the firm reinforced their 'narcissistic propensity to see their world primarily as an arena in which to exercise power and seek glory' (Owen \& Davis, 2009). As David Mabey and his family had all the power to appoint or remover M\&J directors, their actions could not be challenged by anyone. In this regard, the absence of appropriate family business governance framework or road map for the founder-entrepreneur and their successive directors seemed to have heightened the hubristic tendencies of Bevil Mabey.

\section{Organizational level}

Our case evidence suggest that the self-interest of the Mabey family and its directors, overtime, evolved into a common collective interest of M\&J-winning contracts through bribery. The evolving corporate culture which fuelled executive hubris at M\&J promoted specialised language and phrases coined to describe, record, and conceal M\&J's activities. For example, bribes were referred to as: Local 
costs, local party funds, contract consultancy, marketing costs, and future contracts. Expressed in oftused catch phrases like 'commission' or 'after sale service', kickback at M\&J became an integral part of the organisation's discourse and got embedded into everyday business practices of managers (Fein \& Weibler, 2014). In under-estimating the risk involved in bribery, an upshot of progressive hubris, the fund created for the payment of bribes in Ghana was ironically named Ghana Development Fund (GDF). Pinto, Leana \& Pil (2008) argues that, whilst organisations could benefit from such activities, individuals involved tend to be the direct beneficiaries. In this case, the firm (Mabey Family Trustees Ltd) owned by the directors was the majority shareholder in the Mabey Group. Consequently, the copious rationalisation of the taken-for-granted illegal behaviour became a standard operational procedure at M\&, and the use of agents was not just an effective way to share, transfer, and moderate the consequences of their unethical business practices (Anand, Ashforth \& Joshi, 2004; Smarzynska and Wei, 2000).

At best, they were used as a conduit to deny involvement or knowledge of the illicit activities taking place abroad. Consumed by hubris, the executives over time perceived bribery as morally justifiable (Collins, Uhlenbruck \& Rodriguez, 2009), exaggerated the firms performance (Jiang, Stone, Sun, \& Zhang, 2011), which in turn led to excessive media coverage for the firm. Consistent with the observation of Magnam, Cormier \& Lapointe-Antunes (2013) that nearly all CEOs involved in fraudulent activities experienced positive media coverage; M\&J was frequently in the news as having delivered some of the largest bridge construction projects in the UK and overseas. In recognition for his services to the export industry, the firm's founder, Bevil Mabey received the award of Commander of the Order of the British Empire (CBE) in 1984. The company also received six Queen's Awards (1973, 1978, 1982, 1987, 1998 and 2002) for Export Achievement. The media frequently attributed the firm's superior performance to the stellar management of the firms operations around the world. Such achievements and media glorifications reinforced the executives' sense of selfimportance (Hayward and Hambrick, 1997), which in turn reinforced the executives' belief they could get away with paying of bribes to secure contracts around the world. 


\section{Institutional level}

The responsive institutions, ostensibly required to check the activities of firms, to make sure they are operating within the 'rules of the game', rather fuelled executive hubris at M\&J. This manifested in the form of three specific outcomes that characterised the broader environmental context within which M\&J was embedded. The first was the lagging anti-bribery UK legislations regulating foreign corrupt practices among UK firms. For example, the UK has been accused to be reluctant in adopting any anti-bribery laws until 2010 (ITV1, 2012; Yeo, 2011). Even at the time of implementation, there were serious attempts by government to 'water it down'. Furthermore, Horder (2011) observes that section 13 of UK's Bribery Act 2010 justifies the use of bribery by intelligence services in cases of advancing economic interests for the UK.

Second, the lack of political will to rein in British firms suspected of bribing to secure contracts abroad. As argued by Gilbert \& Sharman (2014), the UK government is known for showing a lenient attitude towards bribery, known for intervening in bribery investigations, and even manipulating the data in reports for OECD. In addition, the ECGD on countless occasions has also been accused of backing projects in countries with severe corruption problems (Hawley, 2003). In this case, allegations of M\&J's corruption were raised by anti-corruption groups to the ECGD in 2003. The ECGD in response completed a review of its guarantee for M\&J's $£ 17 m$ contract in Jamaica, but concluded that: 'There is no great cause for concern'. The outcome of such investigation, we found, emboldened M\&J executives in their illegal activities.

Finally, the lax regulations and lack of political will to clamp down on corrupt practices of British firms resulted in inefficient external controls in terms of governance and corporate social responsibilities mechanisms employed by M\&J to guide their operating practices. Operating within a context where external controls were ineffective (Yeoh, 2011), hubris among M\&J executives grew faster and lead to supervisory deficiencies, manipulation of rules and laws governing ownership structures, and the delusion of being responsible to themselves alone (Hollow, 2014). In terms of its 
legal status and ownership structure, M\&J throughout its history remained a family business. The Mabey family were the majority shareholders, with David Mabey acting as the company Secretary and his five sisters as board members. The significance of this was that the Mabey family had exclusive control of M\&J, appointed directors', and far less accountable to shareholders. The powerful voices of family shareholders with controlling interests who didn't see the need to dilute their control justified and rationalised their unethical actions, unrestrained.

\section{Discussions and Conclusions}

The international business literature has long focused on the antecedents and outcomes of firms paying bribes to secure contracts and deals around the world. Our goal in this paper is to contribute to this inquiry by advancing our understanding on how established international businesses organize their bribery activities. In so doing, we introduce a new factor into the equation: the influence of executive hubris in driving bribery. Specifically, we provide a detailed account of how hubris as played out in the form of impetuous personality traits such as charisma, charm, ability to inspire, willingness to take risk, grandiose aspirations, and over-confidence may lead to the normalization of bribery in firms. At the core of our study, we delineate the organizing practices of firms and their representatives, and the schemes they employ to organise their bribery activities. The leitmotif of our theorizing is that executive hubris, excessive confidence or arrogance which frequently leads business executives to believe they are exempt from established mores, invincible, or may do no wrong, is important for extending our understanding as to why bribery in international businesses have become so pervasive and frequently used as a Darwinian business tool (Nobel, 2013) by many firms to undermine their commercial rivals. The empirical focus of our study was the bribery scandal involving M\&J, the first British firm to be convicted for bribing foreign government officials to secure contracts. Our case evidence suggests that the company at the behest of its executives operated a bribery scheme that run parallel with government tendering processes in Ghana and Jamaica. The organizing logic of the scheme, as operated by M\&J was to appoint representatives or agents who 
bribed party and government officials in these countries in return for contracts. M\&J in addition went further to set up a special fund from which its agents were paid.

Our case analysis offered several insights that provided support for our arguments that executive hubris played a major role in the routinization and normalization of bribery as an acceptable business practice at M\&J. First, the founder of the company, over several years established personal connections with the ruling class in various host countries and these individuals acted as agents to further M\&J's interest in exchange of commissions. Having powerful friends abroad simplified M\&J's contract acquisitions and provided the firm protection from possible prosecution both at home and abroad. From a hubristic perspective, the firm simply had contempt for authority and, established mores and anti-bribery legislations. Cognitively, the founder developed a sense of being above the law, and considered himself uniquely and eternally qualified to run the company (Petit \& Bollard, 2012). We learned that the normalization and perpetuation of the bribery culture (Anand, Ashford, \& Joshi, 2004) established by the founder led to future executives of M\&J being socialised into it paying bribes to secure contracts for the firm. The most evident sign of hubristic behaviour was the establishment of a cross-national scheme to bypass the legitimate tendering processes in the host countries. In achieving overwhelming success in securing major contracts, executives became extremely powerful and excessively confident to the extent they could swiftly replace agents who lost favour with their governments with much powerful ones. The subsequent special "development fund" set up by M\&J to pay agents' commissions appeared to have also increased their "narcissistic propensity to see their world primarily as an arena in which to exercise power and seek glory" (Owen \& Davidson, 2009: 132), a hubristic behaviour that burgeoned into a fully-fledged syndrome that gave form to and shaped the reckless and impulsive actions of the executives. These patterns of hubristic behaviours exhibited by the firm's executives had features frequently triggered by power, which in turn, effectively insulated the executives from the day-to-day realities, which Owen \& Davidson (2009) argue is often associated with progressive isolation. From 
this perspective the firm's success strengthened M\&J's executives' belief in their managerial and leadership capabilities, feeding into their sense of self-importance, pride, and confidence in their own capabilities (Hayward \& Hambrick, 1997).

The M\&J scandal also sheds light on how the context within which the firm operated contributed to its bribery activities. Our analysis suggests various contextual factors combined to fuel the executive hubris we report, which in turn drove the illegal practices that took place at M\&J. We unpack these factors which manifested themselves in different ways to fuel the hubristic behaviour of M\&J's executives on three main levels to develop our hubris-bribery heuristic framework. The first comes into representation at the individual level. Here we identified personal, political, and official ties and the extended executive tenures as the overarching factors that fuelled hubris among the executives of M\&J. Such 'powerful' ties, we argue, led to the grandiose sense of self among the executives (Petit \& Bollaert, 2012), which in turn made them feel they were above law and that they could never be brought to justice. The second is the organizational level where factors ranging from the organizational culture, the awards, accolades, and press glorification combined to strengthen the belief of executives that the company's success was a result of their 'excellent leadership'. Entrenching the bribery culture established in the firm, these meso-level factors combined to fuel the hubristic behaviour of M\&J executives by bolstering their egos, and making them believe they were uniquely and eternally qualified to run the company. The third was related to institutional level controls in the form of lack of political will and inefficient external controls. For example, the UK government acted to protect the company's interests when complaints about M\&J's corrupt activities in the Philippines were made to the British ambassador in Manila; who after David Mabey's visit and personal assurance quickly dismissed these claims as opposition's fabrications to discredit the Philippine president (Leigh \& Evans, 2005). Thus, the UK government in the past, showing lenient attitude towards bribery and even help large British firms with political and economic clout to find "useful" people to bribe in foreign governments in order to promote British business (Gilbert, \& Sharman, 
2014). Here the unchecked power, lack of monitoring/control, and the absence of punishment fuel executive hubris which in turn may increase the likelihood of corruption.

Our study contributes to the theory and practice of bribery in international business in two ways, which in turn directs attention to some promising directions for future research. First, in drawing on hubris as a lens to examine bribery, we shed light on how executive cognition and behaviour may influence the propensity for firms to engage in bribery to further their interests. Since the M\&J scandal and the subsequent imprisonment of its executives, 25 other British companies including Glasgow based Weir Group, Eastbourne based Smith, Macmillan Publishers Limited, and many other European firms like Siemens and Daimler-Chrysler have also been convicted of bribery abroad (Fernando, Flah, Gottwald, \& Hauch, 2013). We invite future research to examine whether executive hubris played a part in these cases. Second, our hubris-bribery heuristic framework provides rich clues to better understand the organizing context within which executive hubris is likely to fuel bribery. Taken together these findings suggest that our understanding of the prevalence of bribery in international business is incomplete without an explicit consideration of the influence of the context within which the wider external environment and internal representations might constitutively fuel executive hubris, which in turn may lead to a firm to engage in bribery. In this regard, our hubris-bribery framework lends itself to further conceptual and empirical extension of the practice of bribery in international business. While our focus has been on M\&J's executives, future research could examine whether hubris could account for the behaviour of the government officials who colluded with M\&J to engage in their bribery practices. In this regard, we suggest refining of our framework to account for external environmental factors in host countries that might have contributed in facilitating or encouraging firms to institutionalise bribery as a route to securing contracts.

Finally, at a time when anti-bribery legislations are beginning to bite hard in many parts of the world, our study has some practical implications for executives and firms keen on controlling 


\section{References}

Anand, V. Ashforth, B. E., \& Joshi, M. (2004) Business as usual: The acceptance and perpetuation of corruption in organizations. The Academy of Management Executive, 18(2), pp. 39-53.

Anderson, R., Martin, G. S., \& Reeb, D. (2015) Family Ownership and Financial Misrepresentation.

Aidt, T. S. (2003) Economic analysis of corruption: a survey. The Economic Journal, 113(491), $632-652$.

Ashforth, B. E., \& Anand, V. (2003) The normalization of corruption in organizations. Research in Organizational Behavior, 25, pp. 1-52.

Ashforth, B. E., Gioia, D. A., Robinson, S. L., \& Trevino, L. K. (2008). Re-viewing organizational corruption. Academy of Management Review, 33(3), 670-684.

Bandura, A. (2002) Selective moral disengagement in the exercise of moral agency. Journal of Moral Education, 31(2), 101-119.

Baughn, C., Bodie, N. L., Buchanan, M. A., \& Bixby, M. B. (2010) Bribery in international business transactions. Journal of Business Ethics, 92(1), 15-32

Beenen, G., \& Pinto, J. (2009) Resisting organizational-level corruption: An interview with Sherron Watkins. Academy of Management Learning E Education, 8(2), 275-289.

Bendahan, S., Zehnder, C., Pralong, F. P., \& Antonakis, J. (2014) Leader corruption depends on power and testosterone. The Leadership Quarterly, 26 (2), 101-122 
Benson, M. L. (1985). Denying the Guilty Mind: Accounting for Involvement in a White-Collar Crime. Criminology, 23(4), 583-607.

Benson, M. L., \& Moore, E. (1992) Are white-collar and common offenders the same? An empirical and theoretical critique of a recently proposed general theory of crime. Journal of Research in Crime and Delinquency, 29(3), 251-272.

Bollaert, H., \& Petit, V. (2010) Beyond the dark side of executive psychology: Current research and new directions. European Management Journal, 28(5), 362-376.

Bollaert, H., \& Petit, V. (2012) Flying too close to the sun? Hubris amongst CEOs and how to prevent it. Journal of Business Ethics, 108(3), 265-283.

Brennan, N. M., \& Conroy, J. P. (2013) Executive Hubris: The Case of a Bank CEO. Accounting, Auditing and Accountability Journal, 26(2), 172-195.

Brown, T. (1993) Are you Suffering from Managerial Hubris? The word is seldom used in business. But it can be fatal. Industry Week. 1 ${ }^{\text {st }}$ November 1993.

Brown, E., \& Cloke, J. (2011) Critical perspectives on corruption: an overview. Critical Perspectives in International Business, 7(2), 116-124.

Brown, R. \& Sarma, N. (2007) CEO Overconfidence, CEO Dominance and Corporate Acquisitions. Journal of Economics and Business 59(5), 358-379.

Camerer, C., \& Lovallo, D. (1999). Overconfidence and excess entry: An experimental approach. American Economic Review, 89 (1), 306-318.

Chatterjee, A., \& Hambrick, D. C. (2007) It's all about me: Narcissistic chief executive officers and their effects on company strategy and performance. Administrative Science Quarterly, 52(3), 351- 386.

Claxton, G., Owen, D., \& Sadler-Smith, E. (2015) Hubris in leadership: A peril of unbridled intuition? Leadership, 11(1), 57-78.

Coleman, J. W. (1989) The Criminal Elite: The Sociology of White-Collar Crime. 2nd ed. St. Martin Press: New York.

Collins, J. D., Uhlenbruck, K., \& Rodriguez, P. (2009) Why firms engage in corruption: A top management perspective. Journal of Business Ethics, 87(1), 89-108.

Cuervo-Cazurra, A., (2016). Corruption in international business. Journal of World Business, 51(1), 3549.

Daily Guide (2010) M\&J Fined £4.6 Over Ghana Bribe 26/05/2010 [Online] Available from: http://www.ghanaweb.com/GhanaHomePage/NewsArchive/artikel.php?ID=182877 [Accessed 29 January 2015]

Daily Guide (2009) Bribe Scandal Hits Castle 26/09/2009 [Online] Available from: http://www.ghanaweb.com/GhanaHomePage/NewsArchive/artikel.php?ID=169365 [Accessed 02 February 2015]

Davis E. (2015) Bottom line: corruption. [Online] Available from: http://www.bbc.co.uk/programmes/b05xhyrr\#auto (Accessed 20th Jun 2015) 
Economist (2008) Grease my Palm: Bribery and Corruption have Become Endemic. [Online] Available from: http://www.economist.com/node/12628030[Accessed 02 February 2015]

Engle, E. (2011) I Get by with a Little Help from My Friends? Understanding the UK Anti-Bribery Statute, by Reference to the OECD Convention, and the Foreign Corrupt Practices Act. In Understanding the UK Anti-Bribery Statute, by Reference to the OECD Convention, and the Foreign Corrupt Practices Act (November 3, 2010). The International Lawyer (American Bar Association) (Vol. 44, pp. 1173-1188).

Engelen, E., Ertürk, I., Froud, J., Johal, S., Leaver, A., Moran, M., \& Williams, K. (2012) Misrule of experts? The financial crisis as elite debacle. Economy and Society, 41(3), pp. 360-382.

Essuman B. (2009) M\&J Bribe: How the British Tricked Us. 05/10/2009 [Online] Available from: http://www.ghanaweb.com/GhanaHomePage/NewsArchive/artikel.php?ID=169849

[Accessed 02 February 2015]

Evans, R. and Leigh, D. (2005) British family firm accused of getting rich by building bridges to nowhere. [Online] Available from: http://www.theguardian.com/politics/2005/dec/20/uk.freedomofinformation [Accessed 19 February 2015]

Evans, R. and Leigh, D. (2008) Court Battle Over Secret Export Commissions Claims 02/01/2008 [Online] Available from: http://www.theguardian.com/uk/2008/jan/02/scamsandfraud.money [Accessed 19 February 2015]

Evans, R. and Leigh, D. (2009) British firm Mabey and Johnson convicted of bribing foreign politicians. [Online] Available from: http://www.theguardian.com/business/2009/sep/25/mabey-johnson-foreign-bribery [Accessed 19 February 2015]

Fame (2015) Reports: Previous directors - Mabey and Johnson Limited. [Online] Available from: https://fame2.bvdep.com/version-201572/Report.serv? CID=43\&context=1BGFBJI6TSMTGM [Accessed 24 February 2015]

Fein, E. \& Weibler, J. (2014a) Cognitive basis for corruption and attitudes towards corruption in organizations viewed from a structuralist adult developmental meta-perspective. Behavioral Development Bulletin, 19(3),1-59.

Fein, E., \& Weibler, J. (2014b) Review and shortcomings of literature on corruption in organizations in offering a multi-faceted and integrative understanding of the phenomenon. Behavioral Development Bulletin, 19(3), 1-40.

Fernando, F. M., Flah, A., Gottwald, D. \& Hauch, J. M. (2013) Left Out of the Bargain: Settlements in Foreign Bribery Cases and Implications for Asset Recovery. World Bank Publications.

Finkelstein, S. Hambrick, D. C. \& Cannella, A. A. (2009) Strategic leadership: Theory and research on executives, top management teams, and boards. Oxford University Press.

Ghana Public Procurement Authority (2003) Tender Documents: Procurement of Goods International Competitive Tendering [Online] Available from: 
http://www.ppaghana.org/documents/STD2010/Standard\%20Tender\%20Document\%20for\%2 0Procurment $\% 20$ of\%20Good\%20-\%20ICT.pdf?story id=44 [Accessed 29 May 2015]

Gilbert, J. A. \& Sharman, J. C. (2014) Turning a Blind Eye to Bribery: Explaining Failures to Comply with the International Anti-corruption Regime. Political Studies, 64(1), 74-89.

Gilliland, A. and McKemmish, S. (2004) Building an infrastructure for archival research. Archival Science, 4(3-4), 149-197.

Glaser, M., Schäfers, P. \& Weber, M. (2008) Managerial optimism and corporate investment: Is the CEO alone responsible for the relation? In AFA 2008 New Orleans Meetings Paper. October

Goel, A. M, \& Thakor, A. V. (2008) Overconfidence, CEO selection, and corporate governance. Journal of Finance, 63(6), pp. 2737-2784

Gye Nyame Concord (2009) Miles Potter: The Man Who Paid Sipa \& Co. Ghana Web 17/10/2009 [Online] Available from: http://www.ghanaweb.com/GhanaHomePage/NewsArchive/artikel.php?ID=170420 [Accessed 29 January 2015]

Hawley, S. (2003) Turning a Blind Eye: Corruption and the UK Export Credits Guarantee Department. Corner Hourse. 1-79

Hayward, M. (2007) Ego check: Why executive hubris is wrecking companies and careers and how to avoid the trap. Chicago: Kaplan Publishing. pp. 1-251

Hayward, M. L., \& Hambrick, D. C. (1997) Explaining the premiums paid for large acquisitions: Evidence of CEO hubris. Administrative Science Quarterly, 42(1), 103-127

Hayward, M. L., Shepherd, D. A., \& Griffin, D. (2006) A hubris theory of entrepreneurship. Management Science, 52(2), 160-172.

Hellman, J., Jones, G., \& Kaufmann, D. (2003) Seize the state, seize the day: State capture, corruption, and influence in transition. Journal of Comparative Economics, 31(4), 751-774.

Hietala, P., Kaplan, S. N., \& Robinson, D. T. (2002) What is the price of hubris? Using takeover battles to infer overpayments and synergies (No. w9264). National Bureau of Economic Research. Massachusetts: Cambridge, MA.

Hiller, N. J. \& Hambrick, D. C. (2005) Conceptualizing executive hubris: the role of (hyper-) core selfevaluations in strategic decision-making. Strategic Management Journal, 26(4), 297-319.

Hollow, M. (2014) The 1920 Farrow's Bank failure: a case of managerial hubris? Journal of Management History, 20(2), 164-178.

Hope, C. (2009) Mabey \& Johnson's corruption confession could lead to more SFO investigations. [Online] Available from: http://www.telegraph.co.uk/finance/newsbysector/constructionandproperty/5797671/Mabeyand-Johnsons-corruption-confession-could-lead-to-more-SFO-investigations.html [Accessed 19 February 2015] 
Horder, J. (2011) On Her Majesty's Commercial Service: Bribery, Public Officials and the UK Intelligence Services. The Modern Law Review, 74(6), 911-931.

Huse, M. (2007). Boards, governance and value creation: The human side of corporate governance. Cambridge University Press.

ITV1. (2012) No bribes please! We're British (2012) [Online] Available from: https://www.youtube.com/watch?v=3cZmipA9wUo [Accessed 16 February 2015].

Jiang, F., Stone, G. R., Sun, J., \& Zhang, M. (2011) Managerial hubris, firm expansion and firm performance: Evidence from China. The Social Science Journal, 48(3), 489-499.

Kroll, M. J., Toombs, L. A., \& Wright, P. (2000) Napoleon's tragic march home from Moscow: Lessons in hubris. The Academy of Management Executive, 14(1), 117-128.

Lee, A.S. (1991) Integrating positivist and interpretive approaches to organizational research. Organization Science, 2(4), 342-365.

Leigh D. \& Evans, R. (2008) Court battle over secret export commissions claims, Guardian [Online] https://www.theguardian.com/uk/2008/jan/02/scamsandfraud.money [Accessed 29 July 2015]

Li, J., \& Tang, Y. I. (2010) CEO hubris and firm risk taking in China: The moderating role of managerial discretion. Academy of Management Journal, 53(1), 45-68.

Logsdon, J. M., \& Wood, D. J. (2005) Global business citizenship and voluntary codes of ethical conduct. Journal of Business Ethics, 59(1-2), 55-67.

Mabey Group (2015) Mabey: Mr BG Mabey. [Online] Available from: http://www.mabeygroup.co.uk/heritage/bevil-mabey/ [Accessed 29 January 2015]

Mallin, C. (2016) Corporate Governance, Oxford University Press, Oxford 5 th Edition.

Malmendier, U., \& Tate, G. (2005) CEO overconfidence and corporate investment. The Journal of Finance, 60(6), 2661-2700.

Magnam, M., Cormier, D., \& Lapointe-Antunes, P. (2010) Like MothsAttracted to Flames: Managerial Hubris and Financial Reporting Frauds. Cahier de recherche. Chaire d'information financière et organisationnelle (ESG-UQAM), France.

Magnam, M., Cormier, D. \& Lapointe-Antunes, P. (2013) Financial Reporting Fraud: A Manifestation of Hubris in the C-Suite? Some Exploratory Evidence." http://www.daedalustrust.org.uk/2013/02/financial- reporting-frauds-a-manifestation-ofhubris-in-the-c-suite-some-exploratory-evidence-2013/. [Accessed 29 January 2015]

Maxwell, J. A. (2012). Qualitative Research Design: An Interactive Approach, Sage Publications: London.

Méon, P. G. \& Sekkat, K. (2005) Does corruption grease or sand the wheels of growth? Public Choice, 122(1), 69-97. 
Mishina, Y., Dykes, B. J., Block, E. S. \& Pollock, T. G. (2010) Why “good" firms do bad things: The effects of high aspirations, high expectations, and prominence on the incidence of corporate illegality, Academy of Management Journal, 53(4), 701-722.

Moore, C. (2008a) Moral disengagement in processes of organizational corruption. Journal of Business Ethics, 80(1), 129-139.

Moore, D. A. \& Healy, P. J. (2008b) The trouble with overconfidence. Psychological review, 115(2), 502.

Myjoyonline (2009) M\&J Bribery Scandal: Boniface used bribe money for School Fees [Online] Available from: http://www.ghanaweb.com/GhanaHomePage/NewsArchive/artikel.php?ID=169330 [Accessed 29 January 2015]

Naldi, L., Nordqvist, M., Sjöberg, K., \& Wiklund, J. (2007) Entrepreneurial orientation, risk taking, and performance in family firms. Family Business Review, 20(1), 33-47.

Nobel, C. (2013) "The real cost of bribery", Harvard Business School Working Knowledge, 4 November, available at: http://hbswk.hbs.edu/item/7325.html (accessed 10 November 2017).

Office of the Contractor-General of Jamaica (2011) The National Contracts Commission Jamaica: A Quick Guide to Contract Awards [Online]. Available from: http://www.ncc.gov.jm/ncc/guides to contracts award.php [Accessed 26 May 2015].

Owen, L. D. (2006) Hubris and nemesis in heads of government. Journal of the Royal Society of Medicine, 99(11), 548-551.

Owen, D. (2008) Hubris syndrome. Clinical Medicine, 8(4), 428-432.

Owen, D. \& Davidson, J. (2009) Hubris syndrome: An acquired personality disorder? A study of US Presidents and UK Prime Ministers over the last 100 years. Brain, 132(5), 1396-1406.

Petit, V. \& Bollaert, H. (2012) Flying too close to the sun? Hubris among CEOs and how to prevent it. Journal of Business Ethics, 108(3), 265-283.

Picone, P. M., Dagnino, G. B., \& Minà, A. (2014) The origin of failure: A multidisciplinary appraisal of the hubris hypothesis and proposed research agenda. The Academy of Management Perspectives, 28(4), 447-468.

Pinto, J., Leana, C. R., \& Pil, F. K. (2008) Corrupt organizations or organizations of corrupt individuals? Two types of organization-level corruption. Academy of Management Review, 33(3), 685-709.

Rodriguez, P., Uhlenbruck, K., \& Eden, L. (2005) Government corruption and the entry strategies of multinationals. Academy of Management Review, 30(2), 383-396.

Russell, G. (2011) Psychiatry and politicians: the 'hubris syndrome'. The Psychiatrist, 35(4), 140-145.

Sanyal, R. N. \& Samanta, S. K. (2004) Determinants of bribery in international business. Thunderbird International Business Review, 46(2), 133-148. 
1

2

3

4

5

6

7

8

9

Sanyal, R. (2005) Determinants of bribery in international business: The cultural and economic factors. Journal of Business Ethics, 59(1-2), 139-145.

Sanyal, R. (2012) Patterns in international bribery: Violations of the foreign corrupt practices act Thunderbird International Business Review 54(3), 299-309.

Schein, E. (2004) Organizational culture and leadership. 3ed. John Wiley \& Sons. San Francisco

Sherman, W.S. \& Garland, G.E. (2007). Where to bury the survivors? Exploring possible ex post effects of resistance to change. SAM Advanced Management Journal, 72(1), 52-63.

Shleifer, A. \& Vishny, R.W. (1993) “Corruption”. Quarterly Journal of Economics. 108, 599-617.

Shleifer, A. \& Vishny, R. (1998). The Grabbing Hand. Harvard University Press, Cambridge, MA

SFO (2011) Mabey \& Johnson directors made illegal payments to Sadam Hussein's Iraq to gain contract. [Online] Available from: http://www..gov.uk/press-room/press-releasearchive/press-releases-2011/mabey--johnson-directors-made-illegal-payments-to-sadamhussein\%27s-iraq-to-gain-contract.aspx [Accessed 12 May 2015]

SFO (2012) Shareholder agrees civil recovery by SFO in Mabey \& Johnson. [Online] Available from: http://www.sfo.gov.uk/press-room/latest-press-releases/press-releases-2012/shareholderagrees-civil-recovery-by-sfo-in-mabey--johnson.aspx [Accessed 12 May 2015]

SFO (2015) Bribery \& Corruption: Definitions. [Online] Available from: http://www.sfo.gov.uk/bribery--corruption/bribery--corruption.aspx [Accessed 2 May 2015]

Smarzynska, B. K. \& Wei, S. J. (2000) "Corruption and Composition of Foreign Direct Investment: Firm-Level Evidence," NBER Working Paper No. 7969 , Cambridge, Massachusetts: National Bureau of Economic Research.

Smith, R. (2003) Audit committees combined code guidance. London: Financial Reporting Council.

Southwark Crown Court (2009a) Regina-v-Mabey and Johnson Limited: Prosecution Opening Notes on Ghana and Jamaica, Crown Prosecution Service: London.

Southwark Crown Court (2009b) Regina-v- Mabey and Johnson Limited: Prosecution Transcript of the Sentence Hearing 10am - 4.50pm on Ghana and Jamaica, Crown Prosecution Service: London.

Southwark Crown Court (2011) Regina-v- Mabey and Johnson Limited: Prosecution Opening Notes on Iraq, Crown Prosecution Service: London.

Steidlmeier, P. (1999). Gift giving, bribery and corruption: Ethical management of business relationships in China. Journal of Business Ethics, 20(2), 121-132.

Statesman (2009) Five NDC Cabinet Members Linked to \$40M Bribery Case in UK. Ghana Web 17/08/2009 [Online] Available from: http://www.ghanaweb.com/GhanaHomePage/NewsArchive/artikel.php?ID=166986 [Accessed 29 January 2015] 
Straub, S. (2008) Opportunism, corruption and the multinational firm's mode of entry. Journal of International Economics, 74(2), 245-263.

The High Court of Justice Chancery Division (2007a) Mabey and Johnson Limited vs Jonathan Laszlo Danos, Barry Joyce, Deryck a Gibson Limited and Deryck Gibson. Claim No. HC06C04511, Crown Prosecution Service: London.

The High Court of Justice Chancery Division (2007b) Mabey and Johnson Limited vs Jonathan Laszlo Danos, Barry Joyce, Deryck a Gibson Limited and Deryck Gibson. Defence and Part 20 Counterclaim of the First Defendant. Claim No. HC06C04511, Crown Prosecution Service: London.

Thompson, A., Peteraf, M., Gamble, J., Strickland III, A.J. and Jain, A.K. (2013) Crafting E Executing Strategy 19/e: The Quest for Competitive Advantage: Concepts and Cases. McGraw-Hill Education.

Thorne, S. (2016) Interpretive Description: Qualitative Research for Applied Practice (Vol. 2). Routledge: London.

Trevino, L. K. (2004) Out of touch-The CEO's role in corporate misbehavior, Brook Law Review, 70 (4), 1195-1211.

Turnbull, S. (2011) How Do Multiple Boards Provide Operating Advantages? Finance and Corporate Governance Conference, Available at SSRN: Available from: http://dx.doi.org/10.2139/ssrn.1706069 [Accessed 10 June 2017]

Vissak, T. (2010) Recommendations for using the case study method in international business research. The Qualitative Report, 15(2), 370-388.

Wiggins, B.J. (2011) Confronting the dilemma of mixed methods. Journal of Theoretical and Philosophical Psychology, 31(1), 44-60.

Williamson, O. (1984) The economics of governance: Framework and implications. Journal of Institutional and Theoretical Economics, 140 (1) 195-223.

Wu, X. (2009) Determinants of bribery in Asian firms: Evidence from the world business environment survey. Journal of Business Ethics, 87(1), 75-88.

Zeleni, V. (2016) Corruption, Foreign Direct Investment, and International Marketing in the Western Balkans, Thunderbird International Business Review, 58(3), 277-291.

Zhou, J. Q. \& Peng, M. W. (2012) Does bribery help or hurt firm growth around the world? Asia Pacific Journal of Management, 29(4), 907-921.

Yeoh, P. (2011) The UK Bribery Act 2010: contents and implications. Journal of Financial Crime, 19(1), 37-53. 
Table 1: Framework for diagnosing CEO hubris

\begin{tabular}{|c|c|c|c|}
\hline Context & Scope & Cognitive aspects & Behavioural aspects \\
\hline \multirow[t]{5}{*}{ Power } & & Has a grandiose sense of self & $\begin{array}{l}\text { Grandiose communication style (use } \\
\text { of the royal "we"; use of superlatives; } \\
\text { expression of overarching ambition) }\end{array}$ \\
\hline & $\begin{array}{l}\text { Relation with } \\
\text { the self }\end{array}$ & $\begin{array}{l}\text { Overestimates his/her abilities, } \\
\text { power and likelihood of success }\end{array}$ & $\begin{array}{l}\text { Unjustifiably grandiose projects, } \\
\text { Poor decisions }\end{array}$ \\
\hline & & $\begin{array}{l}\text { Considers him/herself uniquely } \\
\text { and eternally qualified to run the } \\
\text { company }\end{array}$ & $\begin{array}{l}\text { Entrenchment strategies } \\
\text { (accumulation of power; failure to } \\
\text { accept removal from position; tardy } \\
\text { resignation when circumstances } \\
\text { would seem to dictate it) }\end{array}$ \\
\hline & $\begin{array}{l}\text { Relation with } \\
\text { others }\end{array}$ & $\begin{array}{l}\text { Considers him/herself above the } \\
\text { community of humans }\end{array}$ & $\begin{array}{l}\text { Management by fear; violence or } \\
\text { intimidation; refusal of advice or } \\
\text { criticism }\end{array}$ \\
\hline & $\begin{array}{l}\text { Relation with } \\
\text { the world }\end{array}$ & $\begin{array}{l}\text { Considers him/herself above the } \\
\text { law or the gods }\end{array}$ & $\begin{array}{l}\text { Fraud, manipulation of rules and } \\
\text { laws, contempt towards authorities }\end{array}$ \\
\hline
\end{tabular}

Source: Petit and Bollaert (2012)

Table 2: M\&J Executives' tenure

\begin{tabular}{lcc}
\hline Director & Length of service & Years in executive position \\
\hline Bevil Mabey & $1953-2007$ & 54 \\
Richard Forsyth & $1992-2008$ & 16 \\
Alan Daliday & $1992-2008$ & 16 \\
David Mabey & $1993-2008$ & 15 \\
Richard Glover & $1995-2009$ & 14 \\
Miles Potter & $1999-2008$ & 9 \\
\hline
\end{tabular}

Source: Fame, 2015 
Table 3: Examples of illicit payments made by M\&J to government officials

\begin{tabular}{ll}
\hline Dates & \multicolumn{1}{c}{ Ghana } \\
\hline Between & $-£ 55,000$ for 'Contract consultancy' to Minister of roads and highway \\
December & $-£ 500$ to Deputy Minister of Roads and Highways \\
1994 and 18 & $-£ 10,000$ to Director of Legal and International Affairs, Ministry of Finance \\
August 1999 & $-£ 10,000$ ex minister of Roads and Highway \\
& $-£ 5,000$ the director of the Legal and International Affairs at the Ministry of \\
& Finance at the Export Credit Guarantees Department, Ministry of finance. \\
& $-£ 15,000$ to Minister of Health \\
& $-£ 10,000$ to the Chairman inter-city transport corporation \\
& - Cheque of $£ 500$ as 'additional education expense' to the son of a Desk Officer \\
\hline Dates & \\
\hline & \\
Between 20 & -Minister of State in the Ministry of Transport and Works over the years \\
November & received approximately $£ 100,134.62$ \\
October 2001 & - M\&J's Agent was paid 12.5\% of the Jamaica 1 contract price \\
\hline
\end{tabular}

